\title{
MADUREZ PERSONAL COMO CAPACIDAD DE COMPROMISO
}

Rosario Sánchez Muñiz

\section{RESUMEN}

Todo acto de amor es una dádiva, un don. El acto de amor por el que dos personas se comprometen en matrimonio, es una entrega de la propia persona a la persona del amado. Esta entrega presupone cierta auto posesión de quien se dona. No podemos darnos a nosotros mismos, si previamente no nos poseemos; y esta posesión se va logrando con la madurez.

El amor, para que realmente lo sea, debe ser libre y será tanto más libre cuanto mejor sea nuestro propio conocimiento y el conocimiento del otro.

\section{INTRODUCCIÓN}

Los animales no son capaces de amar porque están atados a sus instintos; pueden parecer libres, al menos externamente, pero siempre actúan por instinto. Los seres humanos también tenemos instinto pero podemos moderarlo (por ejemplo, comer menos), controlarlo (por ejemplo, no dejarnos llevar por la ira), desviarlo (por ejemplo, no querer conservar alguna imagen en nuestra imaginación), desenfrenarlo (por ejemplo, beber todo el alcohol que pueda) o sublimarlo (por ejemplo, cuando el sentimiento acompaña al amor). Todo esto gracias a la libertad, por la que podemos dirigirnos a los fines que previamente hemos elegido. 
«Para los seres que no están dotados de razón, las leyes de la naturaleza, son por sí mismas leyes de la existencia; para el hombre son, además, pistas para el pensamiento, temas que rigen la experiencia. Y esta experiencia, en su forma consciente, se obtiene a partir de la profundidad" ${ }^{1}$. Al profundizar en temas como el amor, desentrañamos su significado más profundo lo cual nos ayudará a vivirlo en plenitud desde el inicio de nuestro matrimonio.

En la juventud se vive la experiencia amorosa, en gran medida, como algo impuesto por un destino desconocido que despierta en nosotros una pasión: de pronto, sin saber cómo ha sucedido, estamos enamorados. De este hecho de experiencia surge el refrán: "Sobre el corazón no se manda". Es verdad que en el enamoramiento influyen componentes orgánicos que nos llevan a exclamar: "Entre nosotros no hay química" o viceversa. Pero también influye la fantasía con la que coloreamos los hechos, haciendo que parezcan mejores de lo que, en realidad, son. Y a fin de cuentas, interviene nuestra inteligencia y voluntad, que, valorando los pros y los contras de la otra persona, nos hace decir: "Sí quiero salir contigo".

Dejando de lado el proceso del enamoramiento, quiero enfatizar que el amor es un acto libre, el acto más libérrimo que podemos ejecutar; nadie puede obligarnos a que nos enamoremos de una persona concreta. El amor será tanto más libre cuanto mejor nos conozcamos y cuanto mayor autodominio poseamos. Del mismo modo, cuanto mejor conozcamos al otro, tanto mejor podremos aceptar la donación que de su persona nos hace.

Por la libertad nos dirigimos de manera autónoma a nuestro destino. Pero, ¿cómo destinarse a otro -que eso es el enamoramiento- si por el desconocimiento o la falta de dominio personal, la libertad no puede ejercitarse en plenitud?

${ }^{1}$ Wojtyla Karol., El don del amor., pp.53-54. 
Por eso, el título de este escrito hace referencia a la madurez personal como elemento indispensable para poder comprometerse. La persona madura es objetiva a la hora de juzgarse y también valorar a los demás (aunque este rasgo es difícil de lograr, ya que la interpretación proviene siempre de un sujeto y, por lo tanto, conserva cierta subjetividad); nadie puede creerse suficientemente maduro: siempre podremos crecer en madurez. Sin embargo, podemos afirmar que una persona es más madura que otra, cuando su percepción de la realidad se acerca bastante a la realidad misma, y que otra persona es más inmadura porque distorsiona la realidad sobre su propia persona o la de los demás, creyendo que sólo ella tiene cualidades y que los demás son culpables de todos los hechos negativos que suceden.

Señalamos que una persona va madurando cuando se responsabiliza de sus propios actos; es decir, cuando va siendo capaz de responder a las consecuencias que se siguen de sus elecciones. Esta responsabilidad se nota en la forma como realiza sus tareas y cumple sus obligaciones. Una persona que no es responsable no puede comprometerse. El compromiso es el "acuerdo obtenido mediante concesiones recíprocas" ${ }^{2}$, ya que al no responder de sus actos, no cumplirá con lo acordado. Esto resulta de vital importancia al tratarse del matrimonio, pues la "concesión recíproca" es, en este caso, el propio cuerpo: "Te concedo mi cuerpo para que lo trates como si fuera el tuyo"; si la persona que recibe el don no es capaz de responder, las heridas que causará en el otro serán profundas, ya que el acuerdo no recae sobre sus bienes o sobre algo de poca monta, sino sobre sí mismo.

Una persona madura es flexible. En las relaciones humanas, muchas veces será necesario disminuir la tensión que provocan los conflictos con un poco de flexibilidad: no otorgará tanta importancia a lo que carece de ella; no dogmatizará de aquello

${ }^{2}$ El pequeño Larousse ilustrado., p. 270. 
que es opinable; sabrá reírse de sus propios fallos, y a la vez, tendrá claro lo que es bueno y lo que es malo, no cediendo en los principios que rigen su conducta.

Una persona es madura cuando reflexiona, cuando piensa en las razones íntimas que lo llevan a actuar en un determinado sentido, sin dejarse llevar por el impulso del momento.

Una persona madura coloca la sexualidad en el nivel que le corresponde y sabe donarse a sí misma en una relación sexual acogiendo al otro como un don y no como un instrumento que se usa. Por tratarse de una donación al otro, sólo se dona con una determinada y única persona, valorándola como dádiva definitiva en el tiempo.

Finalmente, una persona madura tiene capacidad de amar. "Para Aristóteles era "el gozo y el deseo de engendrar en la belleza”. Los neoplatónicos lo ven como la ruta fundamental para el conocimiento. Platón decía: "El amor es como una locura (...) es un dios poderoso que produce el conocimiento y lleva al conocimiento"; en el Banquete se esfuerza por probar que el amor perfecto se manifiesta en el deseo del bien; el forastero de Mantinea muestra a Sócrates al final de esta obra que el amor es la contemplación pura de la belleza absoluta.

"Ortega nos dice en Estudios sobre el Amor que amar una cosa es estar empeñado en que exista. Joseph Pieper dice que amar es aprobar, celebrar que eso que se ama está ahí, cerca de uno" ${ }^{3}$.

El amor humano es una inclinación natural que tiene por objeto el bien. "La mujer puede fácilmente parecerle un bien al hombre y viceversa. Esta facilidad con que nace la recíproca atracción es el fruto de la tendencia sexual, particularidad y fuerza de la naturaleza humana, pero fuerza actuante en las personas y que, por ello, exige ser elevada a su nivel" " ${ }^{4}$.

Posee dos fuentes u orígenes distintos: uno sensible y otro espiritual. El amor sensible se origina en el apetito concupiscible

${ }^{3}$ Rojas E., La conquista de la voluntad., p.144.

${ }^{4}$ Wojtyla Karol., Amor y responsabilidad., p. 77. 
y es una pasión que se expresa como afecto que puede llegar a tener una gran fuerza; cuando lo sentimos hacia otra persona, surgen pensamientos como: "No puedo vivir sin ella", "Eres mi vida”.

El amor espiritual se origina en la voluntad. Este amor tiene una conexión muy profunda con el conocimiento intelectual ya que nadie puede amar lo que no conoce. El amor recto hacia uno mismo consiste en orientarse hacia el acabamiento personal, el cual se consigue cuando amamos a otras personas, y al ser Dios la más perfecta de las Personas, mi acabamiento personal consistirá en amarlo por encima de los demás seres. El amor humano es un reflejo de este Amor que Dios es.

Ama en forma madura, quien quiere lo mejor para el que ama; es decir, que el amado sea mejor conmigo que sin mí. Es más perfecto el acto de amar cuando confluyen estas dos fuentes u orígenes distintos, pero a veces esto no es posible porque los estados de ánimo escapan a nuestro control, y entonces será amor verdadero el amor espiritual que se origina en la voluntad, aun cuando la sensibilidad no responda. Afirma Tomás Melendo: “(...) que el amor humano genuino se encuentra esencialmente constituido por un acto de voluntad, y que sin la intervención activa de ésta, en ningún sentido cabría hablar de amor de benevolencia o amor de amistad entre los hombres" 5 . Si el amor fuera puro sentimiento no podríamos comprometernos para siempre.

\section{RESPETO Y CONFIANZA}

El amor supone el respeto ante el ser del amado: único e irrepetible. Respetarlo significa aceptarlo como es, tratando de comprender su forma de actuar, sus cambios en la forma de pensar. Aceptar al otro supone respetar su punto de vista, que puede ser distinto o contrario al propio. Enamorarse no

\footnotetext{
${ }^{5}$ Melendo Tomás., Ocho lecciones sobre el amor humano., p.81.
} 
consiste en seleccionar algunas características que nos atraen de la otra persona, excluyendo o negando otras que nos interesan menos. Existen mujeres que se enamoran de la inteligencia del hombre, de su prestigio profesional o de su cuenta bancaria, al mismo tiempo que odian su orden excesivo, o sus bobbies. Hay hombres que se enamoran del físico de una mujer, o de su amabilidad, al mismo tiempo que odian que hable tanto, o su impuntualidad. Unas y otros se equivocan al elegir de esta manera; el amor personal no se satisface con fragmentos, sino que busca la totalidad del otro.

Una persona que no se acepta a sí misma, tampoco podrá aceptar a los demás. Quien ama sabe entregarse en la convivencia diaria mediante una actitud de servicio generoso en los mil pequeños detalles que componen la vida familiar. Amar supone que quien ama, está más ahí donde ama, que en donde respira. Así lo expresa el poeta:

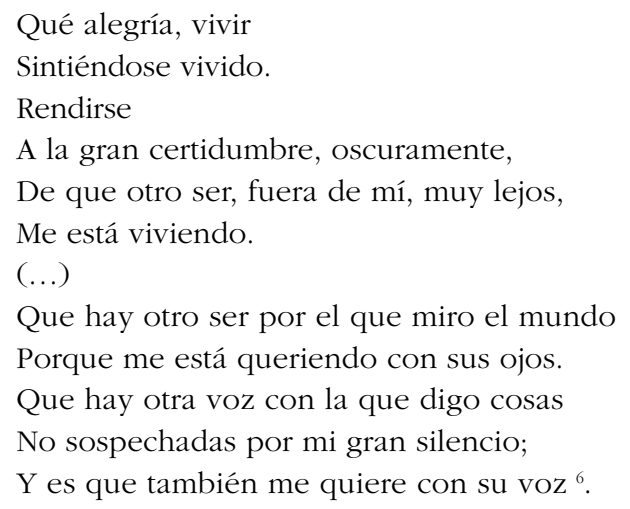

Este hecho que se experimenta cuando nos enamoramos, lo expresa el lenguaje con esta expresión: "Desvivirse por el otro", vivir desde el otro, contemplar la realidad como el otro la ve, llegar a una compenetración tan profunda que nos permite entendernos con la mirada, sin necesidad de palabras.

\footnotetext{
${ }^{6}$ Salinas Pedro., La voz a ti debida., p. 35.
} 
Respetar al amado es ayudarlo a lograr la perfección a la que está llamado, desde su simple desenvolvimiento social, el desarrollo cultural y profesional, hasta el ámbito de sus relaciones con Dios. Ningún ámbito en el que se desenvuelve la persona amada nos es indiferente. Sin embargo, el amor no atropella, ni coacciona, no obliga; invita y espera respetando la libertad de la otra persona.

La confianza es la seguridad que depositamos en el otro: se la ha ganado, nos colocamos bajo su cuidado, nos entregamos. ¿Cuál es la razón para confiar en él? La familiaridad, el trato que nos permite conocerlo y saber qué podemos esperar de él. La confianza es un elemento frágil, susceptible de romperse, pero muy necesario en la relación entre hombre y mujer porque, para poder entregarnos, tenemos que saber que el otro nos recibe sin recelos, y para poder recibir el amor del otro tenemos que confiar en él.

El fundamento de la confianza es la sinceridad. La sinceridad es la base de cualquier relación humana, podemos comunicarnos porque creemos que la otra persona nos dice la verdad; cuando esa relación es amorosa, la sinceridad se vuelve indispensable, porque el amor o es confianza, o no es amor.

\section{COMUNICACIÓN ENTRE HOMBRE Y MUJER}

La persona humana experimenta la necesidad de expresar sus sentimientos, pensamientos y deseos. La comunicación surge de la decisión personal de abrir la intimidad. La propia intimidad sólo yo la conozco. Mis pensamientos no los conoce nadie, hasta que los expreso. En la intimidad está el motor del comportamiento. Cuando comparto esa intimidad con alguien, ese don ha de ser recibido, de lo contrario el don se frustra. La falta de diálogo motiva casi todas las discordias y la falta de comunicación arruina los matrimonios.

"La comunicación, la capacidad de diálogo sincero constituye también una nota distintiva de la madurez personal. Entre los adolescentes, en cambio, es muy frecuente que cualquier 
conflicto se exprese a través de la incomunicación, del aislamiento, incluso del mutismo. Por el contrario, la persona madura jamás se repliega sobre sí misma, sino que es permeable, es capaz de suscitar el encuentro dialógico con el otro, cualquiera que sea la naturaleza del conflicto" ${ }^{\text {. }}$.

Comunicar es poseer la habilidad de trasladar desde mi ser hasta el interior del otro, aquello que yo soy. Y cuando se acepta ese regalo como algo valioso, el resultado será la unión. Esta relación entre personas tiene múltiples formas de expresión desde la lingüistica y la conductual, hasta el mismo silencio que es una forma de comunicar. "La metacomunicación es todo aquello que puede ser tomado en consideración como relevante para nuestra interpretación acerca de lo que la otra persona está diciendo o haciendo, al margen del "contenido" manifiesto de lo que dice o hace" 8 .

En la interpretación del mensaje interviene nuestra educación, cultura, experiencias pasadas y prejuicios sobre la otra persona, esto complica bastante la comunicación. Sin contar con que los mensajes emitidos verbalmente siempre van acompañados de mensajes no verbales (postura, sonrisa, gestos...) que generalmente expresan sentimientos, emociones o actitudes que tal vez no querríamos comunicar. Muchas veces, a través de estos mensajes no verbales, nos damos cuenta de si una persona miente o dice la verdad.

Schiller distingue cuatro sistemas de comunicación conyugal:

1. El sistema convencional, sociable, cotidiano y rutinario: este sistema se caracteriza porque las relaciones entre los esposos reposan sobre realidades superficiales, sin entrar en los sentimientos del otro. "¿Qué haremos hoy?", "¿Pagaste la tarjeta de crédito?».

7 Polaino Lorente A., La comunicación en la pareja., p.31.

${ }^{8}$ Idem, p.73. 
2. El sistema directivo, persuasivo, condescendiente y cerrado: en este sistema, el diálogo es manipulativo, pues se busca que el otro haga lo que yo pretendo. No se participa en los sentimientos del otro, sino que sólo se contempla lo que a uno le agrada, y en función de ello, se decide: "Mañana iremos a...".

3. El sistema especulativo, intelectual, reflexivo y serio, aunque seguro: aquí existen ciertas posibilidades de apertura y de confidencialidad, aunque el nivel está cargado de factores racionales. Sin embargo, hay un mayor respeto por el otro, aunque persista el temor a entrar en el mundo de sus sentimientos. "Si te parece, podríamos ir a...". El intento de acercamiento es real, aunque un poco tímido. La puerta que se abre hacia lo confidencial, puede cerrarse fácilmente por el peso de lo racional.

4. El sistema abierto, autorrevelador, autorresponsable y serio, pero con riesgo: es el tipo de comunicación más positiva. Se revela y manifiesta algo del interior, que queda comprometido en la medida en que se expresan los propios sentimientos. "Si con eso te sientes mejor...", "A mí me gustaría, pero si tu prefieres...... En este sistema se da un verdadero contacto de sentimientos, pero conlleva el natural riesgo de expresarlos.

Los cambios psíquicos que pueden sufrir los esposos, también suelen alterar el normal desarrollo de las relaciones interpersonales y de la comunicación entre ellos (la ira, el sufrimiento ansioso o los estados depresivos, etcétera). Sin embargo, si los esposos cuentan con buenas estrategias de comunicación, con expresividad y escucha atenta, su relación será más constructiva que destructiva.

"Cuando un marido manifiesta un comportamiento hostil y airado a su esposa, de forma clara y no agresiva (y le informa acerca de su causa), y ésta procesa esos mensajes afectivos 
de forma empática y comprensiva, hay una alta probabilidad de que juntos solucionen los problemas, de forma que se modifiquen las circunstancias que provocaron aquel desagradable comportamiento. Por contra, si la persona enfadada grita y critica a su cónyuge, y éste le devuelve las críticas aumentadas, en lugar de responderle con la necesaria empatía, es harto probable que se produzca una escalada de comportamientos negativos y agresivos, lo que en modo alguno contribuirá a resolver el problema" "

La satisfacción de cada uno de los cónyuges respecto de su matrimonio está condicionada, en cierto modo, a la facilidad o dificultad que encuentran para comunicarse. Por lo tanto, la comunicación es una herramienta que debe utilizarse a nuestro favor, trabajando juntos por lograr una excelente habilidad comunicativa.

${ }^{9}$ Idem, p.127. 


\section{REFERENCIAS BIBLIOGRÁFICAS}

EL PEQUEÑO LAROUSSE ILUSTRADO., Colombia., Ediciones, 7a. ed., 2001.

POLAINO LORENTE Aquilino y MARTÍNEZ CANO Pedro., La comunicación en la pareja. Errores psicológicos más frecuentes., Navarra., Universidad de Navarra., Instituto de Ciencias para la Familia., Ediciones Rialp., 1999.

ROJAS Enrique., La conquista de la voluntad., Madrid., Ediciones Temas de Hoy., 1994.

SALINAS Pedro., La voz a ti debida., Buenos Aires., Editorial Losada, S. A., 4⿳⺈.e.ed., 1967.

WOJTYLA, Karol., El don del amor., Madrid., Biblioteca Palabra., Ediciones Palabra., 1999.

WOJTYLA, Karol., Amor y responsabilidad., Madrid., Editorial Razón y Fe, S. A., Madrid., 1969. 